\title{
ANTI-MISCEGENATION LAWS IN THE UNITED STATES
}

The word "miscegenation" is not included in the everyday vocabulary of a large part of our citizenry, but there are nonetheless laws in twenty-nine states prohibiting miscegenation. Etymologically, the term means intermarriage of persons of different races; when used in this paper, however, the word has reference to marriage between whites and non-whites.

Without suggesting an opinion on the desirability of antimiscegenation laws, the writer proposes to sketch the provisions and effects of the present statutes on the subject. Various questions then arise: what is the purpose of such . statutes and how effectively are they accomplishing that purpose? Also, what are the legal problems created in applying these laws? 
ANTI-MISCEgENATION LAWS IN THE U. S.

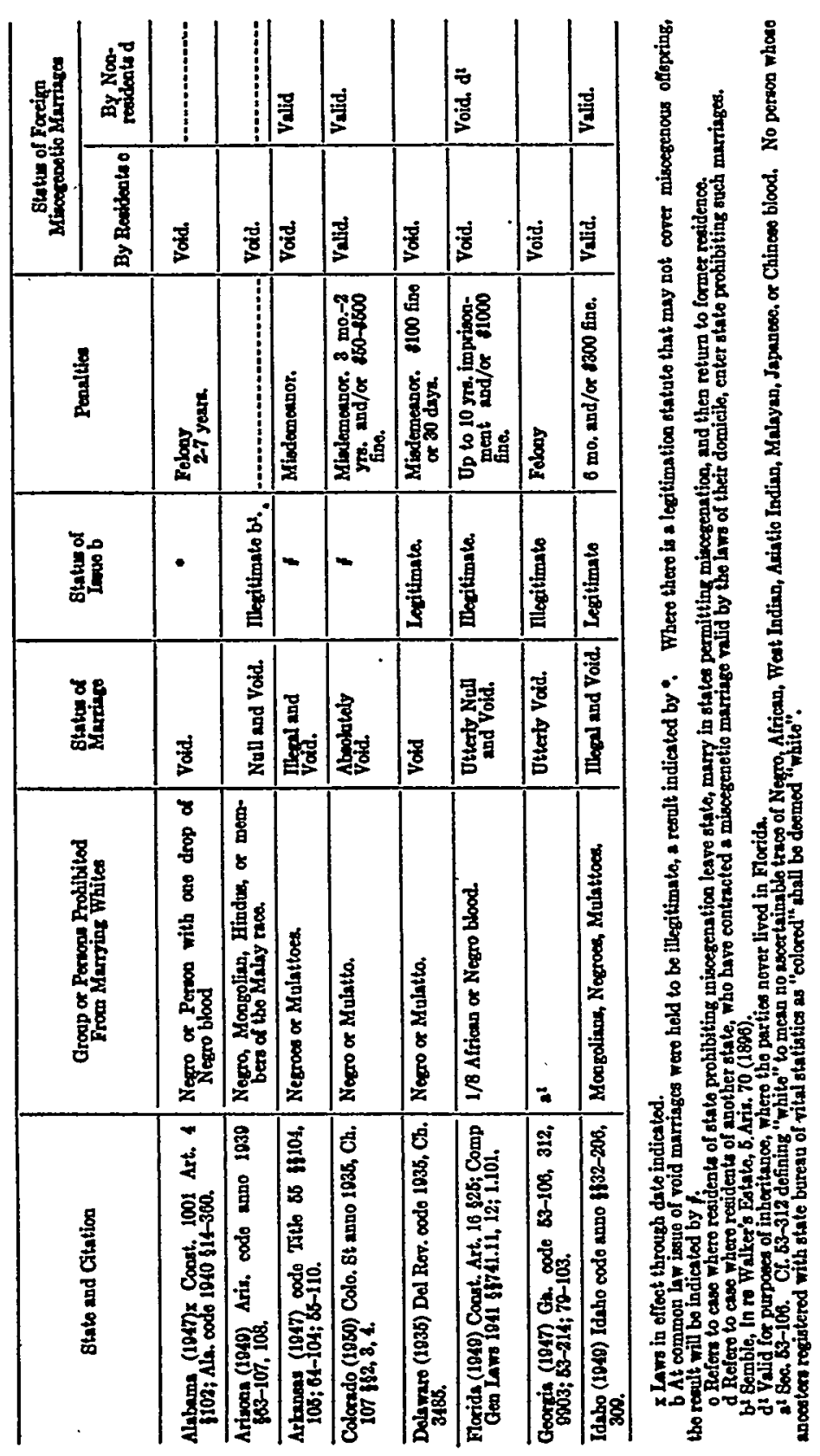




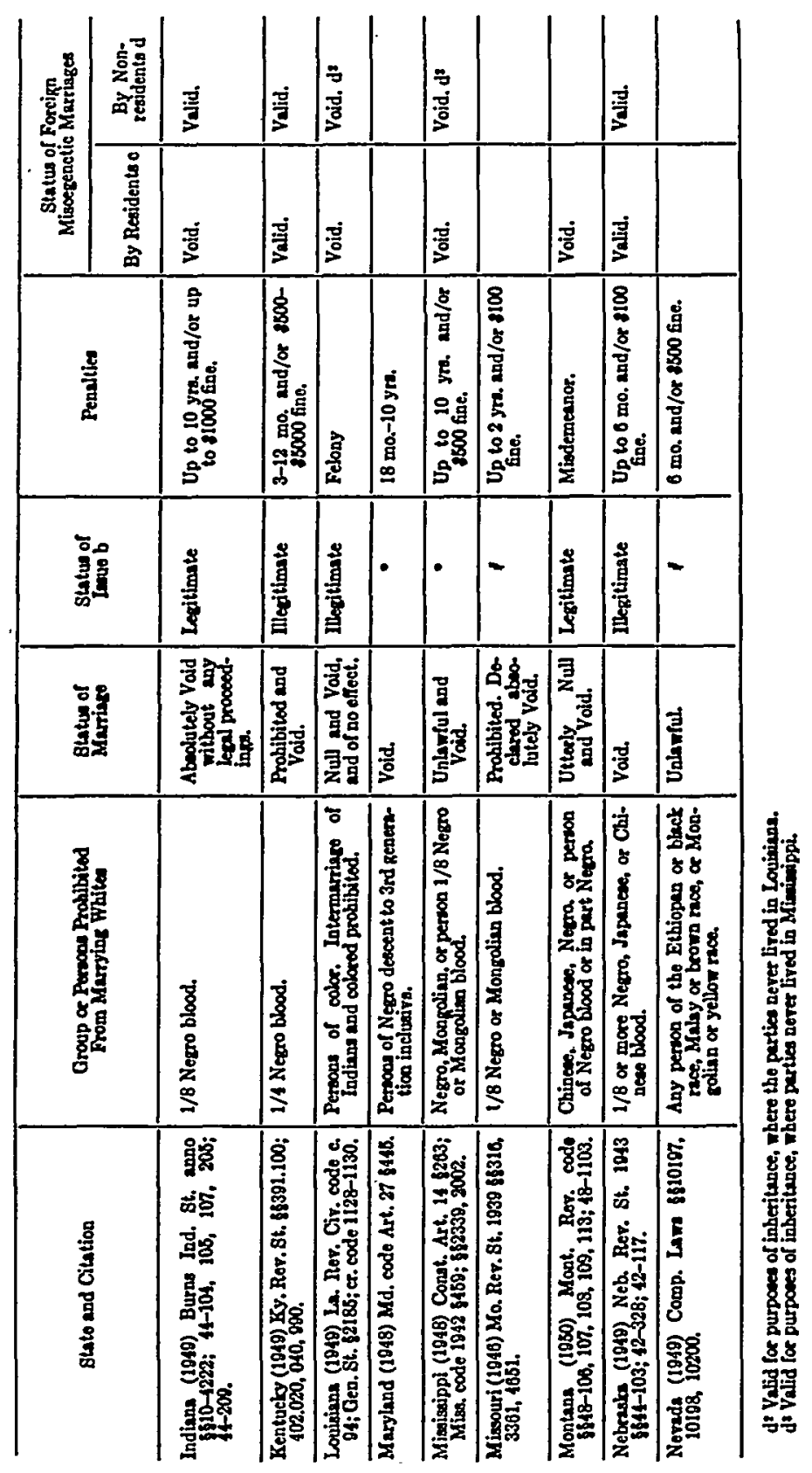


ANTI-MISCEgENATION LAWS IN THE U. S.

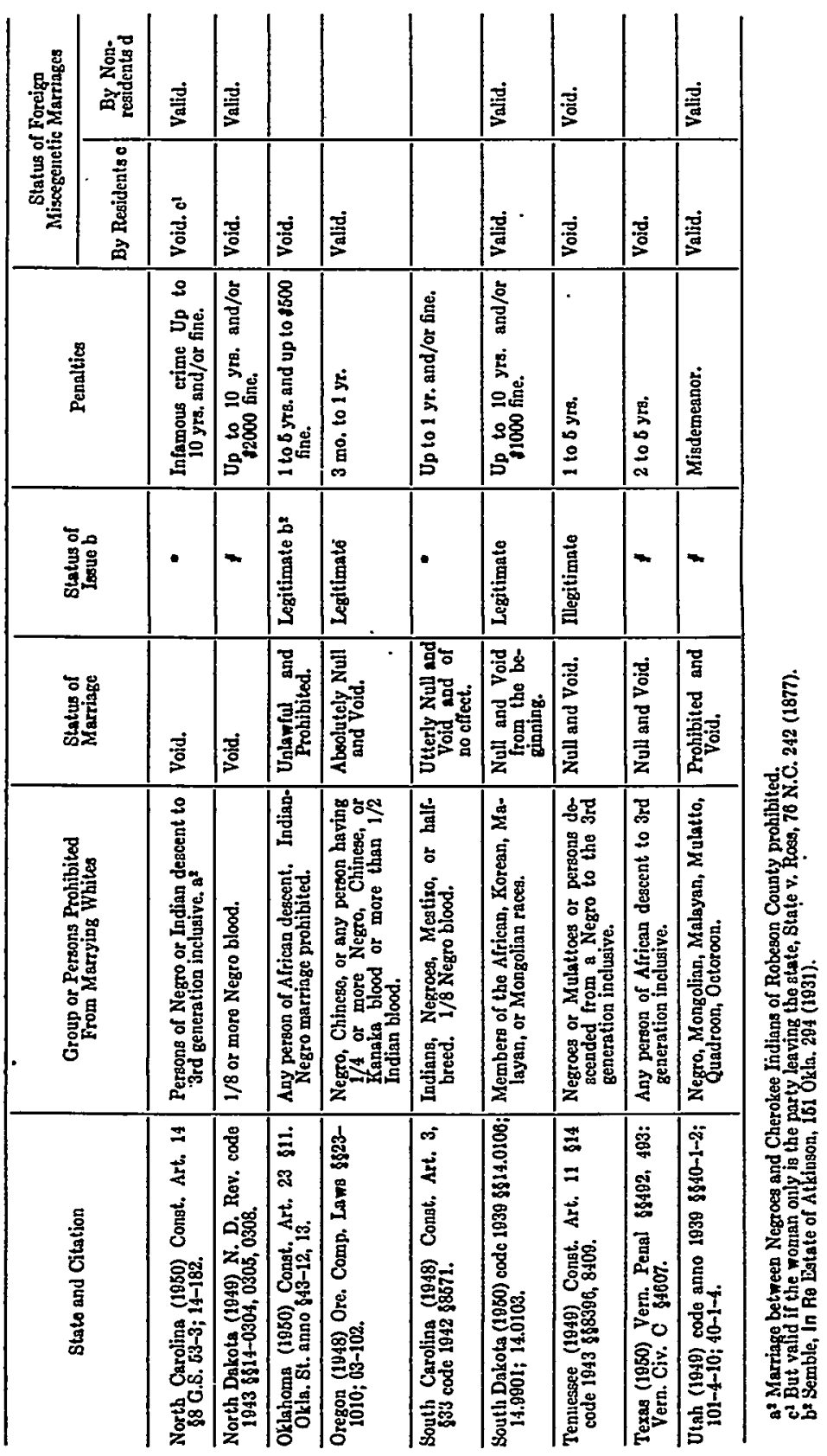




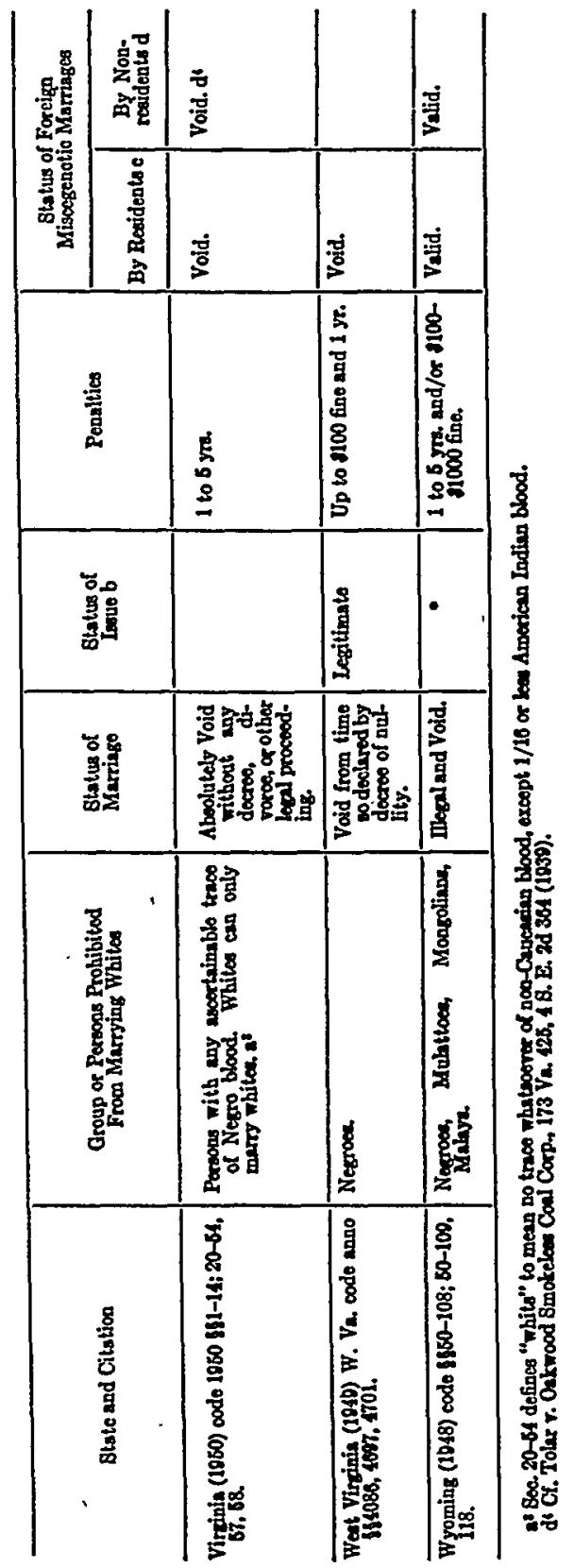




\section{Provisions and Effects of Present Laws}

The preceding chart presents a panorama of the statutory law of the twenty-nine states that have taken steps to prevent miscegenation. As one will note, the laws are about as varied as they are numerous; they disclose differing definitions of those in the prohibited class, the emphasis as to persons in this class significantly shifting with the geographical location of the states. All these states prohibit Negro-white marriages. Fourteen states, chiefly west of the Mississippi, forbid intermarriage of white and Mongoloid persons. ${ }^{1}$ Three states, Louisiana, North Carolina, and Oklahoma prohibit Negro-Indian intermarriage. ${ }^{2}$ Four states forbid Indian-white marriages. ${ }^{8}$ Six states consider racial intermarriage with such abhorrence that its prohibition is provided for in their Constitutions. ${ }^{4}$

In contrast to the common law rule that issue of a void marriage are illegitimate, many states have statutes legitimating such issue. However, some legitimation statutes have been interpreted not to apply to children of miscegenous marriages; others, as indicated on the chart, have not been construed as to this point. Although the status of the issue is uncertain in many states, the marriages themseives seem generally to be void $a b$ initio and not merely voidable.

2 Arizona, Georgia, Idabo, Louisiena, Missouri, Montana, Nebraska, Nevada, Oregon, South Dakota, Utah, Virginia, and Wyoming. There may be some question as to Georgia and Loulslana. Some of the statutes specify the particular Mongolians prohibited, such as Nebraska, and South Dakota.

Malay-phite marriages prohlbited in Arizona, Maryland, Nevada, South Dakota, Utah, Wyoming, and possibly Georgia and Louisiana.

\& Regarding the Oklahoma statute, it is explained that one motive for prohibiting Negro-Indian marriages, was to prevent Negroes from sharing the wealth of those Indians who owned rich oll lands. Schuy. ler, Kacial Intermarriage in the United States, 16 (1929).

Regarding the North Carolina statute, the statute is alleged to be connected with a legend that the Cherokee Indians of Robeson County are descendants of the Croatau Indians who, as the legend has it, intermarried with members of the Lost Colony of Sir Walter Raleigh; therefore, these present Cherokees are part white, and any NegroIndian marriage in this instance would also be Negro-white intermarriage. Btephenson, Race Distinctions in American Laro. 90 (1910).

- North Carolina, Oregon, South Carolina, and Virginia. Possibly Georgia and Loulisiana.

- Alabama, Florida, Mississippl, North Carolina, South Carolina, and Tennespee. 


\section{Sociological Background}

There is no categorical explanation for anti-miscegenation legislation. To attempt such explanation is to become enmeshed in one of the many aspects of the American social milieu. The inconsistency among the statutes in the selection of the minority groups indicates the localization of certain prejudices in this country and collectively, the statutes act as indicators for the animosities nurtured by groups in control in various states. On a national level, however, the picture is incomplete. The absence of anti-miscegenation statutes in some states should not be considered as evidence that such marriages are approved there or that there is a popular indifference to them. Rather, the lack of such laws frequently reflects the fact that Negroes and Orientals are a negligible part of the population in these states, and that intermarriages are so few that the question can be ignored. "Moreover, the absence of such legislation is a source of some pride and it gives a certain feeling of self-righteousness that is luxuriously pleasing."

The passing of the frontier, which provided one method of escape for the minority groups, and the ever increasing occasion for social contact in our present mobile society, serve as catalysts to the inter-group reaction and increase the awareness of the fact that some groups have not assimilated in certain areas. The opportunity of assimilation, which in the ultimate sense must include amalgamation, has been extended to Jewish, Italian and other white minorities;

- Reuter, Race Mixture, 101 (1931). At page 103 the author states that in recent years there have been attempts to pass laws prohibiting the Intermarriage of Negroes and whites in Wiscongin, Massachugetts, Washington, Kansas, Minnesota, Iowa, Illinois, Michigan, Ohio, Penngylvania, and New York.

"The lack of restrictive legislation on racial intermarriage in eighteen states and the District of Columbia does not mean that quasilegal devises to frustrate those marriages are absent. In northern states, where there are no intermarriage statutes, judges often refuse to issue licenses to racially divergent couples. Likewise, in the state of Washington, the county auditor whose task it is to determine whether or not the mentality of applicants for marriage licenses is suitable, often uses this power to deny licenses to potential racial intermarriage. In at least one other state, New Jersey, mental tests have also been used to prevent racial intermarriages." Barron, People Who Intermarry, 56 (1946). 
but colored groups-Black, Brown, Yellow and to a lesser extent Red-are considered unassimilable, and are denied intermarriage with whites.

The underlying animosity to colored minorities can be partially attributed to a desire in white groups to maintain economic and social advantages: Independent of this desire is a wish to avoid the physical consequences which are thought to flow from racial inter-marriage. Thus, as one court put it in upholding the constitutionality of an antimiscegenation statute:

"The amalgamation of the races is not only unnatural but is always productive of deplorable results."6

At times the statutes depart from purely social and economic considerations. The Georgia statute includes within its prohibition, the marriage of whites with Asiatic Indians. What challenge could this minority offer to the economic and social superiority of Georgia whites? Similarly, the Western states prohibit Negro-white marriages. Yet the 1940 census shows that the Negroes constitute less than one per cent of the population of Miontana, North Dakota, South Dakota, Wyoming, Nevada, and Oregon. However useful "color" may be as an instrument for stratification, what role does it play where the "inferior caste" constitutes less than one per cent of the population?

The peculiarities of inclusion or exclusion of various racial groups in anti-miscegenation statutes seem due to fortuitious historical events. Among such events may be mentioned the migration into the state of population groups from regions in which intense racial attitudes are dominant, the rise to power of political leaders holding such attitudes, and a local upsurge of racial feeling due to dramatic incidents of inter-group conflict in the particular state.

Considering that over half of the states have legislation designed to prevent miscegenation, it could reasonably be supposed that a rather formidable problem in that connection existed. Yet studies made of the extent of racial intermarriage in the United States indicate that it is very small;

- Scott v. State, 39 Ga. 321, 324 (1869). Of similar import, Ford v. State, 53 Ala. 150 (1875); Hoover v. State, 59 Ala. 57 (1877); Kennedy จ. State, 76 N.C. 251. (1877); State v. Frasher, 3 Tex. App. 262 (1877). 
of necessity, these studies must be made in states with no prohibitions against such marriages. The bulk of such studies deal with Negro-white intermarriages. One of the later studies of the city of Boston for the years 1914-38 reveals that of all marriages involving whites, the percentage of Negro-white was .13, and for the same period there were 276 Negro-white marriages, which was 3.9 per cent of all marriages involving Negroes.7 A study of New York, exclusive of New York City, for the years 1916-37 revealed that there were 569 Negro-white marriages which accounted for 2.9 per cent of all marriages involving Negroes. ${ }^{8}$ of course, any study in the field is not completely reliable, for the definition of "Negro" may vary with the study conducted.

One interesting survey reveals that the tendency to intermarry appears to vary according to sex. Of 3,131 cases of Negro racial intermarriage in twenty-two American cities, approximately four-fifths were of the Negro male-white female type. ${ }^{\theta}$ From these statistics one can conclude that the Negro male racially intermarries more frequently than does the Negro female and that the converse is true with whites. According to current population figures, the number of white females continues to exceed the number of males, a trend which may be accentuated further by war casualties. Thus, pressure is placed upon the mass of unmarried white females to search further for husbands, a factor which may induce increasing readiness on the part of some to enter into miscegenous unions. Conversely, the white male may feel less resentment toward a miscegenous marriage which only slightly drains the vast reservoir of marriageable females. Still, since Negro females also outnumber Negro males, the Negro man is not under pressure to range afield seeking a whito mate. Whether these demographic trends will cancel out or increase the pressure toward miscegenation cannot be foretold.

In states where the social caste feeling is especially strong it is doubtful that statutes are needed to prevent miscegena-

- Klinebero, Characteristics of the American Negro, 277, tablo 4, (1944).

- Ibia, 280, table 7.

- Barron, op cit., 116-117. 
tion. Probably their chief function is to reenforce and crystallize public sentiment, which may differ from the sentiments held by particular individuals. Also, the statutes may act as a deterrent to prevent "colored" persons from attempting to intermarry with whites even though their physical characteristics would allow them to pass the color line; the statutes remind them of the possible painful consequences to self, and family if their heredity "is discovered.

\section{Conflict of Laws Problems}

The proximity of states that do not interfere with racial intermarriage to those states that do, presents an interesting and complicated conflict of laws question, that has been variously resolved by the states having interdictions against such marriages. ${ }^{10}$ Suppose residents of a state forbidding miscegenation journey to another state condoning it, marry, and then return to their former home. In such instances, it is generally held that the evasion will not bar a criminal prosecution for illegal cohabitation in the domiciliary state, nor will the marriage be valid for any purpose there. ${ }^{11}$ Eighteen of the states have statutes with respect to marriage evasion; of these, three-Indiana, Virginia and West Virginia-require a special intent to evade local law. ${ }^{12}$ Those states which allow their anti-miscegenation laws to be evaded by one who has carfare to another state are keeping nullities on the statute books. ${ }^{13}$

10 "Although as a general rule, validity of a marriage is determined by the law of the place where it was entered into, so that a marriage valid there is generally to be regarded as valid everywhere, there are recognized exceptions to this rule, principal among which are (1) polygamous marrlages, and (2) marriages considered to he incestuous by the universel consent of Christendom. A third exception is sometimes recognized to that general rule in cases of marriages celebrated In another state which are contrary to the public policy of the state as embodied in a statute prohibiting such marriages." 3 A.I.R. 2d, 241.

1. Georgia v. Tutty, 41 Fed. 753 (1890); Dupre $\nabla$. Boulard, 10 La. Ann. 411 (1885); Babisso's Succession, 119 La. 704, 44 So. 438 (1907); State v. Kenneđy, 56 N.C. 251 (1897); Eggers จ. Olson, 104 Okla. 297, 231 P. 483 (1924); Baker v. Carter, 180 Okla. 71, 56 P.2d 85 (1937).

2 Alabama, Arizona, Colorado, Delaware, Georgia, Ideho, Indiana, Kentucky, Louisiana, Mississippi, Montana, Nebraska, North Dakota, South Dakota, Utah, Virginia, West Virginia, Wyoming.

is Idaho, Kentucky, Wyoming, Oregon, Colorado, and Utah. 
If a miscegenous marriage has been consummated by residents of a state where such marriages are permitted, what is the legal effect if the couple subsequently moves to a state forbidding such marriages? Clearly, a state would be less inclined te give effect to its anti-miscegenation statute in this instance than in a case where there had initially been an effort to evade the law. By statute, Colorado, Idaho, Kentucky, Nebraska and Wyoming declare the marriage valid in such cases; North Carohina achieves the same result by decision. As the North Carolina Court put it:

"Our laws have no extra-territorial operation, and do not attempt to prohibit the marriage in South Carolina of blacks and whites domiciled in that state."14

The North Carolina court put an interesting twist on the last statement by invoking the traditional rule that a wife takes the domicile of her husband. Accordingly, it was held that where a white woman had left North Carolina to marry a Negro in a state where such marriages were permitted, the marriage would be recognized in North Carolina, since the wife's prior residence in North Carolina was superseded by her husband's domicile. Such a view opens the door to marriage evasion in the numerically most frequent type of racial intermarriage, that of a white woman and a Negro man, if the Negro is from a state not forbidding miscegenation.

Tennessee takes a contrary stand. ${ }^{18}$ Apparently, any marriage between a Negro and a white person, regardless of whether the parties were legally domiciled and married in a state permitting miscegenation, will not be recognized later in Tennessee. Perhaps this view brings Tennessee into conflict with the Full Faith and Credit clause of the Constitution, for if the parties have never lived in Tennessee, no public policy of that state would seem to justify a refusal to recognize the marriage for such purposes as descent of property in Tennessee. The result would apparently hinge on whether, for purposes of Full Faith and Credit, "marriage" is a "public Act, record, or judicial proceeding."

1* State V. Ross, 76 N.C. 242, 244 (1877).

is State v. Bell, 7 Baxt. (Tenn.) 9 (1872). 


\section{Constitutional Law Problems}

Prior to 1948 anti-miscegenation legislation had received judicial approval on every encounter. Attacks on the validity or constitutionality of the statutes were successfully parried.by the courts. ${ }^{16}$ However, in 1948, the California court in the case of Perez v. Lippold ${ }^{17}$ declared the California anti-miscegenation statute unconstitutional. The question of validity having been aroused from its constitutional slumber, the query arises as to whether these statutes could survive a determined attack in the United States Supreme Court.

One point of vulnerability was vagueness. Sociologically, the line between white and colored is in some instances not clear-cut; for instance, it was estimated as early as 1921 that almost 25,000 Negroes crossed the color line each year.18 The California statute like that in a few other western states failed to deal explicitly with these persons

to Miscegenation statutes held constitutional: Dodson v. State, 61 Ark. 57 (1895); Green v. State, 58 Ala. 150 (1877) ; Ford v. State, supra; Kirby v. Kirby, 24 Ariz. 9 (1932).

Held not to impair the obligation of contract provision of Art. 1, Sec. 10 of the U. S. Constitution: In re Hobbs, 12 Fed. Cas. 6,550 (1871); Maynard v. Hill, 125 U.S. 190 (1887), holding that marriage was not a contract within the meaning of the prohibition; State v. Tutty, 41 Fed. 753 (1890); Dobson v. State, supra.

Held not to violate the equal protection clause of the 14th Amendment of the U.S. Constitution: Green v. State, supra; State v. Gibson, 36 Ind. 389 (1890); State v. Jackson, 80 Mo. 175 (1880); In Re Paquet's Estate, 101 Ore. 393 (1921); Jackson v. Denver, 190 Colo. 196 (1942).

Said the court in State v. Jackson, supra., at 177, "All of one's rights as a citizen of the United States will be found guaranteed by the Constitution of the United States. If any provision of that instrument confers upon a citizen the right to marry anyone who is willing to wed him, our attention has not been called to it."

17198 P. $2 d 17$ (1948). A white woman and a Negro man were denied a marriage license on the basis of Civ. Code Sec. 69 which provided “. . . no license may be issued authorizing the marriage of a white person with a Negro, mulatto, Mongolian, or member of the Malay race." Civ. Code Sec. 60 provided: "All marriages of white persons with Negroes, Mongolians, members of the Malay race or mulattoes are illegal and void." No further definition, as to what percentage of blood would render a person a member of the prohibited class, was given.

38 Hart, Hornell, Selective Migration As a. Factor In Child Welfare in the United States, With Special Reference to Iowa, University of Iowa Studies in Child Welfare, vol. 1, First Series, 1921. Commented on in American Journal of Sociology, LII, (July 1946), 18-22. 
changing races in mid-stream. For this reason, it was felt to be vague; but this argument would presumably not apply to the more specific provisions of most of the other states.

A more involved matter is the question of compatibility with the equal protection clause of the United States Constitution. In the past, relying on the 1896 cases of Plessy $v$. Ferguson, the courts have refused to recognize that such statutes violated the equal protection clause. ${ }^{18}$ They suggested that there was equality of application as to the two races, since whites could not marry outside their race nor Negroes outside their race. On the other hand, the California court in the Perez case treated equality of application not according to races but according to individuals. The argument was followed there that an anti-miscegenation law denies equal protection because $A$, a Negro, is forbidden to marry $\mathrm{B}$, a white; while $\mathrm{C}$, a white, may lawfully marry B. It is said to be irrevelant that A can marry some other Negro.

Efforts have been made to justify the anti-miscegenation statutes as measures designed to protect public peace, health and welfare. For one thing these laws are said to prevent breaches of peace that might occur under the impetus of incidents of racial intermarriage. Such an argnment, however, was rejected by the Supreme Court in Buchanan v. War-

10 163 U.S. $537(1896)$. "... there is no discrimination where the law applies equally to whites and to Negroes." The Plessy formula has since been the vehlcle of the antl-miscegenation cause. However, there has been attenuation of the doctrine: The houslng ordlnance cases, Buchanan v. Warley, 245 U.S. 69 (1917), Harmon v. Tyler, 273 U.S. 688 (1927), Clty of Richmond v. Deans, 281 U.S. 704 (1930). These cases decided that using race or color as a basls for denjing a person equal enjoyment of property rights was discriminatlon, and in violation of the Fourteenth Amendment of the U. S. Constitution. More recently, Oyama v. Californla, 332 U.S. 633 (1948). The 1948 case of Shelly $v$. Kraemer, 68 Sup. Ct. 826 rejected the equallty of appllcatlon doctriue where property rights are concerned, "The rights created by the first section of the Fourteenth Amendment are, by its terms, guaranteed to the individual. It is, therefore, no answer to tbese petitioners to say that the court may also be induced to deny white persons rights of ownership and occupancy on the grounds of race or color. Equal protection of the laws is not achleved through indiscriminate imposition of inequalities." In the education field the doctrine has been refected where substantlal equality, in fact, has not been achleved. Sweatt $\nabla$. Painter, 339 U.S. 629 (1950). In the transportation fleld, Henderson $v$. U.S., 339 U.S. 816 (1950). 
ley which dealt with the validity of zoning ordinances that segregated according to race. ${ }^{20}$ Moreover, to accept this argument would mean that a dominant group could justify any discrimination by threatening to commit breaches of the peace if the discrimination is removed.

The intimate relationship between the marital institution and the basic welfare of the States has been relied upon to justify close supervision by it of the matrimonial ventures of its domiciliaries. Without speculating as to the physical consequences of racial intermarriage, ${ }^{21}$ the writer suggests tbat the sociological effects upon the offspring must be considered. It may well be argued that the state, as parens patriae, has a privilege to bar marriage which would produce problem progeny. To apply this principle one can consider the situation of the child of a mixed marriage.

If white and Negro intermarry, any children will normally be shunned by other whites if the child's parentage is known; and the white parent may not be fully accepted by his child's colored companions. Thus, a gap may develop in the home. More important, under the state segregation laws in many states the white parent will be barred by law from associating with his child in restaurants, theaters, and other public places. Will not the deprivation of the parent's full companionship react adversely upon the child? This suggestion emphasizes that regulation of the family must take account of conditions of society with a view to producing normal children.

Apparently, in making this or other arguments to justify anti-miscegenation laws, the state bears the burden of proving a rational basis for its statute. The usual presumption in favor of constitutionality seems not to be indulged in cases arising under the equal protection clause when funda-

2 Supra.

IT The claims that certain races, especially tbe Negro, are biologically inferior, and the progeny of racially divergent couples are likewise inferior, found some support among early investigators of the subject. The later studies generally tend to discredit such claims. It is signifl. cant that in the Perez case, the minority cited the earlier studies, the majority citing the latest studies available. The case contains a valuable list of the more important studies made in this field. Attention is called to one excellent work by Montague, Man's Most Dangerous Myth: The Fallacy of Race, (1945). 
mental personal rights are involved. ${ }^{22}$ And marriage seems in this category. ${ }^{23}$ Also exceptional circumstances are required to justify discrimination or classification of citizens on the basis of racial descent.24

\section{Conclusions}

Social mobility and inter group contact-some of it fostered by recent Supreme Court decisions-tend to produce surroundings more conducive to miscegenation. Nevertheless test cases similar to Perez v. Lippold, challenging antimiscegenation laws, will probably come slowly to the courts if at all. For one thing, potential plaintiffs are hard to find; and few such persons would desire to suffer possible adverse publicity and other consequences. In the Perez case the parties were seeking by mandamus to compel issuance of a license. But what if the state issues a license without protest, relying solely on the penal provisions? Would there be sufficient standing on the part of plaintiff to challenge these penal provisions before marriage had subjected them thereto? In view of this necessary risk of punishment it is questionable that many persons would go through with the marriage, even if convinced there was a constitutional right to miscegenate. Also, few "civil rights" proponents would be zealous enough in opposition to any statute to incur. matrimonial entanglements in order to be in a position to challenge the statute.

Thus, anti-miscegenation laws will probably remain on the statute books. Perez v. Lippold may have been a defeat

= Truax v. Raich, 239 U.S. 33 (1915); Railway Mail Association v. Corsi, 326 U.S. 88 (1945); Patton v. Mississ!ppl, 332 U.S. 337 (1947); Takahashi v. Fish and Game Commission, 334 U.S. 410 (1948).

This changing of the presumption arose in the cases involving lib. erties protected under the First Amendment. See U.S. v. Carolene Food Products, 304 U.S. 147 (1938).

23 Meyer v. Nebraska, 262 U.S. 300 (1932); Plerce v. Society of Sister, 268 U.S. 510 (1925); Skinner ₹. Oklahoma, 316 U.S. 535 (1942). Said the court in the Skinner case, "We are dealing with leglslation whlch involves one of the basic clvil rights of man. Marriage and procreation are fundamental to the very existence and survival of the race." (Oklahoma's sterilization statute was the legislation involved in that case.)

* Hirabayashi v. U.S., 320 U.S. 81 (1943); Korematgu v. U.S., 323 U.S. 214 (1944); Oyama v. California, supra. 
for proponents of miscegenation, for the decision of the California court prevented recourse to the United States Supreme Court; and thus, whatever "deplorable amalgamation of races occurs" will continue to be through inter-breeding rather than intermarriage.

JAMES R. BROWNING. 